\title{
Male Oxidative Stress Infertility (MOSI): Proposed Terminology and Clinical Practice Guidelines for Management of Idiopathic Male Infertility
}

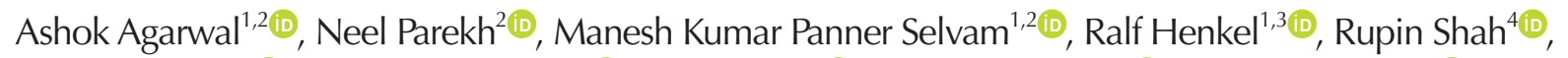

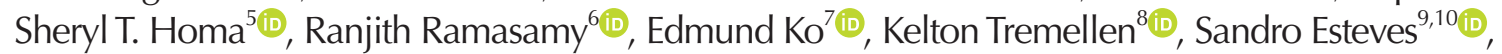
Ahmad Majzoub ${ }^{1,11}{ }^{\mathbb{D}}$, Juan G. Alvarez ${ }^{12}$ (D) David K. Gardner ${ }^{13}$ (D) Channa N. Jayasena ${ }^{14,15}$, Jonathan W. Ramsay ${ }^{15}$, Chak-Lam Cho ${ }^{16}$ (D) Ramadan Saleh $^{17(\mathbb{D}}$, Denny Sakkas ${ }^{18}$, James M. Hotaling ${ }^{19}$,

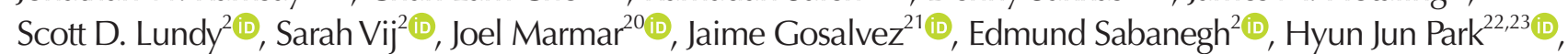
Armand Zini $^{24}$ (D), Parviz Kavoussi ${ }^{25}$ (iD), Sava Micic ${ }^{26}$ (i) , Ryan Smith $^{27}$ (i), Gian Maria Busetto ${ }^{28(\mathbb{D})}$,

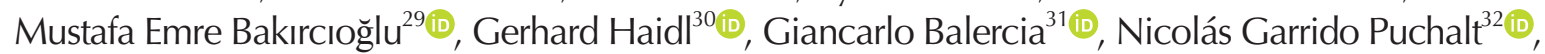
${\text { Moncef Ben-Khalifa }{ }^{33} \text { (D) Nicholas Tadros }}^{34}$ (D), Jackson Kirkman-Browne ${ }^{35,36}$ (i) , Sergey Moskovtsev ${ }^{37(\mathbb{D})}$,

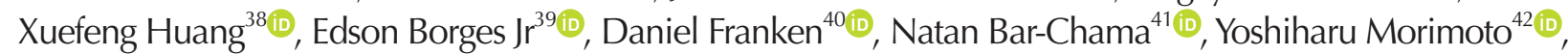

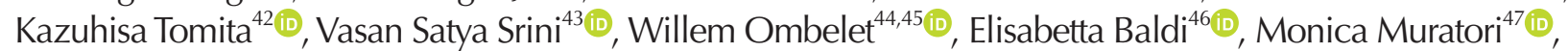
Yasushi Yumura $^{48}$ (D) Sandro La Vignera ${ }^{49}$, Raghavender Kosgi ${ }^{50}$, , Marlon P. Martinez $^{51}$ (D) , Donald P. Evenson $^{52}$,

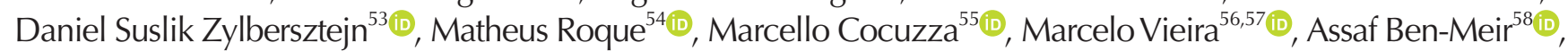
Raoul Orvieto ${ }^{59,60(\mathbb{D})}$, Eliahu Levitas ${ }^{61}$ (D), Amir Wiser $^{62,63(\mathbb{D})}$, Mohamed Arafa $^{64}$ (D) , Vineet Malhotra $^{65}$,

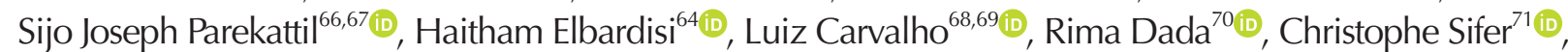
Pankaj Talwar ${ }^{72}$ (i) Ahmet Gudeloglu ${ }^{73}$ (i) , Ahmed M.A. Mahmoud ${ }^{74}$ (i) Khaled Terras $^{75}$ (i) , Chadi Yazbeck $^{76}$, Bojanic Nebojsa ${ }^{77}$ (D) Damayanthi Durairajanayagam ${ }^{78}$ (D) , Ajina Mounir ${ }^{79}$, Linda G. Kahn ${ }^{80}$ (D) Saradha Baskaran $^{1}$ (iD), Rishma Dhillon Pai ${ }^{81}$ (D) , Donatella Paoli ${ }^{82}$ (i) , Kristian Leisegang ${ }^{83(\mathbb{D}}$, Mohamed-Reza Moein ${ }^{84}$, Sonia Malik ${ }^{85}$ (D),

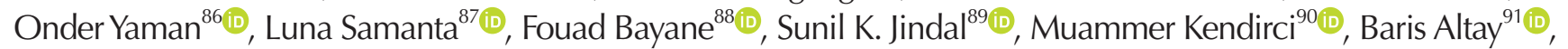
Dragoljub Perovic ${ }^{92}$ (i), Avi Harlev ${ }^{93}$ (1D

${ }^{1}$ American Center for Reproductive Medicine, Cleveland Clinic, ${ }^{2}$ Department of Urology, Cleveland Clinic, Cleveland, OH, USA, ${ }^{3}$ Department of Medical Bioscience, University of the Western Cape, Cape Town, South Africa, ${ }^{4}$ Department of Urology, Lilavati Hospital and Research Centre, Mumbai, India, ${ }^{5}$ School of Biosciences, University of Kent, Canterbury, UK, ${ }^{6}$ Department of Urology, University of Miami, Miami, FL, '7Department of Urology, Loma Linda University Health, Loma Linda, CA, USA, ${ }^{8}$ Department of Obstetrics Gynaecology and Reproductive Medicine, Flinders University, Bedford Park, Australia, ${ }^{9}$ Division of Urology, Department of Surgery, University of Campinas (UNICAMP), Campinas, Brazil, ${ }^{10}$ Faculty of Health, Aarhus University, Aarhus, Denmark, ${ }^{11}$ Department of Urology, Hamad Medical Corporation and Weill Cornell Medicine-Qatar, Doha, Qatar, ${ }^{12}$ Centro Androgen, La Coruña, Spain and Harvard Medical School, Boston, MA, USA, ${ }^{13}$ School of BioSciences, University of Melbourne, Parkville, Australia, ${ }^{14}$ Section of Investigative Medicine, Imperial College London, ${ }^{15}$ Department of Andrology, Hammersmith Hospital, London, UK, ${ }^{16}$ Department of Surgery, Union Hospital, Shatin, Hong Kong, ${ }^{17}$ Department of Dermatology, Venereology and Andrology, Faculty of Medicine, Sohag University, Sohag, Egypt, ${ }^{18}$ Boston IVF, Waltham, MA, ${ }^{19}$ Department of Urology, University of Utah, Salt Lake City, UT, ${ }^{20}$ Cooper University Hospital, Camden, NJ, USA, ${ }^{21}$ Departamento de Biología, Universidad Autónoma de Madrid, Madrid, Spain, ${ }^{22}$ Department of Urology, Pusan National University School of Medicine, ${ }^{23}$ Medical Research Institute of Pusan National University Hospital, Busan, Korea, ${ }^{24}$ Department of Surgery, McGill

Received: Apr 2, 2019 Accepted: Apr 2, 2019 Published online May 8, 2019 Correspondence to: Ashok Agarwal (iD https://orcid.org/0000-0003-0585-1026 American Center for Reproductive Medicine, Cleveland Clinic, Mail Code X-11, 10681 Carnegie Avenue, Cleveland, OH 44195, USA. Tel: +1-216-444-9485, Fax: +1-216-445-6049, E-mail: agarwaa@ccf.org, Website: CCF.org/ReproductiveResearchCenter 
University, Montreal, QC, Canada, ${ }^{25}$ Austin Fertility \& Reproductive Medicine/Westlake IVF, Austin, TX, USA, ${ }^{26}$ Uromedica Polyclinic, Kneza Milosa, Belgrade, Serbia, ${ }^{27}$ Department of Urology, University of Virginia, Charlottesville, VA, USA, ${ }^{28}$ Sapienza University of Rome, Rome, Italy, ${ }^{29}$ Istanbul Florence Nightingale Hospital, Istanbul, Turkey, ${ }^{30}$ Department of Dermatology, University Hospital Bonn, Bonn, Germany, ${ }^{31}$ Division of Endocrinology, Department of Clinical and Molecular Sciences, Polytechnic University of Marche, Umberto I Hospital, Ancona, Italy, ${ }^{32}$ IVI Foundation Edificio Biopolo - Instituto de Investigación Sanitaria la Fe, Valencia, Spain, ${ }^{33}$ University Hospital, School of Médicine and PERITOX Laboratory, Amiens, Frances, ${ }^{34}$ Division of Urology, Southern Illinois University School of Medicine, Springfield, IL, USA, ${ }^{35}$ Centre for Human Reproductive Science, IMSR, College of Medical \& Dental Sciences, The University of Birmingham Edgbaston, ${ }^{36}$ The Birmingham Women's Fertility Centre, Birmingham Women's and Children's NHS Foundation Trust, Mindelsohn Drive, Edgbaston, UK, ${ }^{37}$ Department of Obstetrics and Gynaecology, University of Toronto, Toronto, ON, Canada, ${ }^{38}$ Reproductive Medicine Center, The First Affiliated Hospital of Wenzhou Medical University, Wenzhou, China, ${ }^{39}$ Fertility Medical Group, São Paulo, Brazil, ${ }^{40}$ Department of Obstetrics \& Gynecology, Andrology Unit Faculties of Health Sciences, Tygerberg Hospital, Tygerberg, South Africa, ${ }^{41}$ Department of Urology, Icahn School of Medicine at Mount Sinai, New York, NY, USA, ${ }^{2}$ IVF Japan Group, Horac Grand Front Osaka Clinic, Osaka, Japan, ${ }^{43}$ Manipal Fertility, Bangalore, India, ${ }^{44}$ Genk Institute for Fertility Technology, Genk, ${ }^{45}$ Hasselt University, Biomedical Research Institute, Diepenbeek, Belgium, ${ }^{46}$ Department of Experimental and Clinical Medicine, Center of Excellence DeNothe, University of Florence, ${ }^{47}$ Department of Experimental and Clinical Biomedical Sciences "Mario Serio", Unit of Sexual Medicine and Andrology, Center of Excellence DeNothe, University of Florence, Florence, Italy, ${ }^{48}$ Department of Urology, Reproduction Center, Yokohama City University Medical Center, Yokohama, Japan, ${ }^{49}$ Department of Clinical and Experimental Medicine, University of Catania, Catania, Italy, ${ }^{50}$ Androbest Andrology \& Urology Center, Hyderabad, India, ${ }^{51}$ Section of Urology, University of Santo Tomas Hospital, Manila, Philippines, ${ }^{52}$ SCSA Diagnostics, Brookings, SD, USA, ${ }^{53}$ Fleury Group and Hospital Israelita Albert Einstein, São Paulo, ${ }^{54}$ Origen, Center for Reproductive Medicine, Rio de Janeiro, ${ }^{55}$ Department of Urology, University of São Paulo (USP), ${ }^{56}$ Division of Urology, Infertility Center ALFA, São Paulo, ${ }^{57}$ Head of Male Infertility Division, Andrology Department, Brazilian Society of Urology, Rio de Janeiro, Brazil, ${ }^{58}$ Fertility and IVF Unit, Department of Obstetrics and Gynecology, Hebrew-University Hadassah Medical Center, Jerusalem, ${ }^{59}$ Infertility and IVF Unit, Department of Obstetrics and Gynecology, Chaim Sheba Medical Center (Tel Hashomer), Ramat Gan, ${ }^{60}$ Tarnesby-Tarnowski Chair for Family Planning and Fertility Regulation, Sackler Faculty of Medicine, Tel-Aviv University, Tel Aviv, ${ }^{61}$ Soroka University Medical Center, Ben-Gurion University of the Negev Beer-Sheva, Beersheba, ${ }^{62}$ IVF Unit, Meir Medical Center, Kfar Sava, ${ }^{63}$ Sackler Medicine School, Tel Aviv University, Tel Aviv, Israel, ${ }^{64}$ Department of Urology, Hamad Medical Corporation, Doha, Qatar, ${ }^{65}$ Department of Andrology and Urology, Diyos Hospital, New Delhi, India, ${ }^{66}$ PUR Clinic, South Lake Hospital, Clermont, ${ }^{67}$ University of Central Florida, Orlando, FL, USA, ${ }^{68}$ Baby Center, Institute for Reproductive Medicine, ${ }^{69}$ College Institute of Clinical Research and Teaching Development, São Paulo, Brazil, ${ }^{70}$ Lab for Molecular Reproduction and Genetics, Anatomy, All India Institute of Medical Sciences, New Delhi, India, ${ }^{71}$ Department of Reproductive Biology, Hôpitaux Universitaires Paris Seine Saint-Denis, Bondy, France, ${ }^{72}$ Department of Reproductive Medicine and Embryology, Manipal Hospital, New Delhi, India, ${ }^{73}$ Department of Urology, Hacettepe University Faculty of Medicine, Ankara, Turkey, ${ }^{74}$ Department of Endocrinology/ Andrology, University Hospital Ghent, Ghent, Belgium, ${ }^{75}$ Department of Reproductive Medicine, Hannibal International Clinic, Tunis, Tunisia, ${ }^{76}$ Department of Obstetrics, Gynecology and Reproductive Medicine, Pierre Cherest and Hartman Clinics, Paris, France, ${ }^{77}$ Clinic of Urology, Clinical Centre of Serbia, Faculty of Medicine, University of Belgrade, Belgrade, Serbia, ${ }^{78}$ Department of Physiology, Faculty of Medicine, Universiti Teknologi MARA, Sungai Buloh Campus, Jalan Hospital, Selangor, Malaysia, ${ }^{79}$ Department of Embryology, Faculty of Medicine, University of Sousse, Sousse, Tunisia, ${ }^{80}$ Department of Pediatrics, New York University School of Medicine, New York, NY, USA, ${ }^{81}$ Department of Obstetrics and Gynaecology, Lilavati Hospital and Research Centre, Mumbai, India, ${ }^{82}$ Department of Experimental Medicine, Sapienza University of Rome, Rome, Italy, ${ }^{83}$ School of Natural Medicine, University of the Western Cape, Cape Town, South Africa, ${ }^{84}$ Department of Andrology, Shahid Sadoughi Medical University, Yazd, Iran, ${ }^{85}$ Southend Fertility \& IVF, Delhi, India, ${ }^{86}$ Department of Urology, School of Medicine, University of Ankara, Ankara, Turkey, ${ }^{87}$ Redox Biology Laboratory, Department of Zoology and Center of Excellence in Environment and Public Health, Ravenshaw University, Cutrack, India, ${ }^{88}$ Marrakech Fertility Institute, Marrakech, Morocco, ${ }^{89}$ Jindal Hospital, Meerut, India, ${ }^{90}$ Department of Urology, Istinye University Faculty of Medicine, Liv Hospital Ulus, Istanbul, ${ }^{91}$ Department of Urology, Ege University School of Medicine, İzmir, Turkey, ${ }^{92}$ Center of Urology, CODRA Hospital, Podgorica, Montenegro, ${ }^{93}$ Fertility and IVF Unit, Soroka University Medical Center, Ben Gurion University of the Negev, Beer Sheva, Israel

Despite advances in the field of male reproductive health, idiopathic male infertility, in which a man has altered semen characteristics without an identifiable cause and there is no female factor infertility, remains a challenging condition to diagnose and manage. Increasing evidence suggests that oxidative stress (OS) plays an independent role in the etiology of male infertility, with $30 \%$ to $80 \%$ of infertile men having elevated seminal reactive oxygen species levels. OS can negatively affect fertility via a number of pathways, including interference with capacitation and possible damage to sperm membrane and DNA, which may impair the sperm's potential to fertilize an egg and develop into a healthy embryo. Adequate evaluation of male reproductive potential should therefore include an assessment of sperm OS. We propose the term Male Oxidative Stress Infertility, or MOSI, as a novel descriptor for infertile men with abnormal semen characteristics and OS, including many patients who were previously classified as having idiopathic male infertility. Oxidation-reduction potential (ORP) can be a useful clinical biomarker for the classification of MOSI, as it takes into account the levels of both oxidants and reductants (antioxidants). Current treatment protocols for OS, including the use of antioxidants, are not evidence-based and have the potential for complications and increased healthcare-related expenditures. Utilizing an easy, reproducible, and cost-effective 
test to measure ORP may provide a more targeted, reliable approach for administering antioxidant therapy while minimizing the risk of antioxidant overdose. With the increasing awareness and understanding of MOSI as a distinct male infertility diagnosis, future research endeavors can facilitate the development of evidence-based treatments that target its underlying cause.

Keywords: Infertility, male; MOSI; Oxidation reduction potential; Oxidative stress; Semen

This is an Open Access article distributed under the terms of the Creative Commons Attribution Non-Commercial License (http://creativecommons.org/licenses/by-nc/4.0) which permits unrestricted non-commercial use, distribution, and reproduction in any medium, provided the original work is properly cited.

\section{INTRODUCTION}

Natural conception is a complex process that is achieved in only $76 \%$ to $85 \%$ of couples within 12 months of regular unprotected intercourse [1-5]. The International Committee for Monitoring Assisted Reproductive Technologies (ICMART) defines infertility as the inability to conceive after 1 year of regular, unprotected intercourse [6,7]. The World Health Organization estimates that nearly 190 million people struggle with infertility worldwide and the number of couples seeking medical assistance is steadily rising [8,9]. Among couples unable to conceive, infertility is partially or wholly attributable to a male factor in approximately $50 \%$ of cases (Fig. 1) [10-12]. A variety of conditions can affect male reproductive potential to different extent and they often coexist (Fig. 2) [13-19]. Paradoxically, on routine assessment, the precise etiology of male factor infertility remains undefined in $30 \%$ to $50 \%$ of patients, who are subsequently classified as having

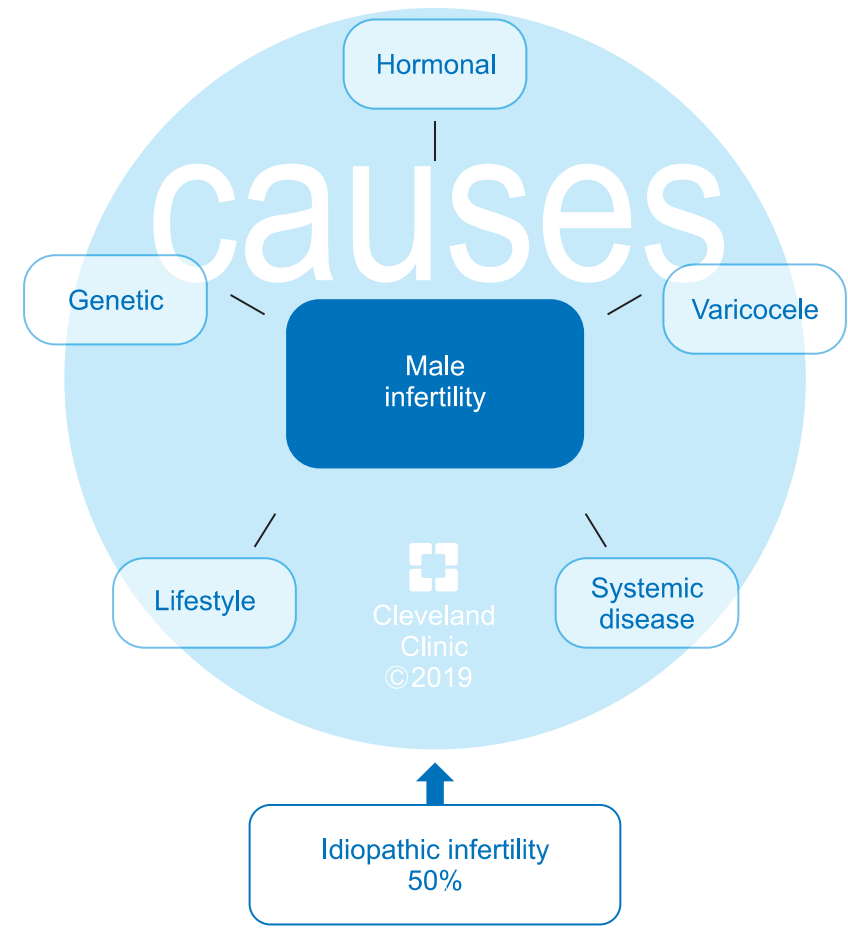

Fig. 2. Conditions affecting male reproductive potential.

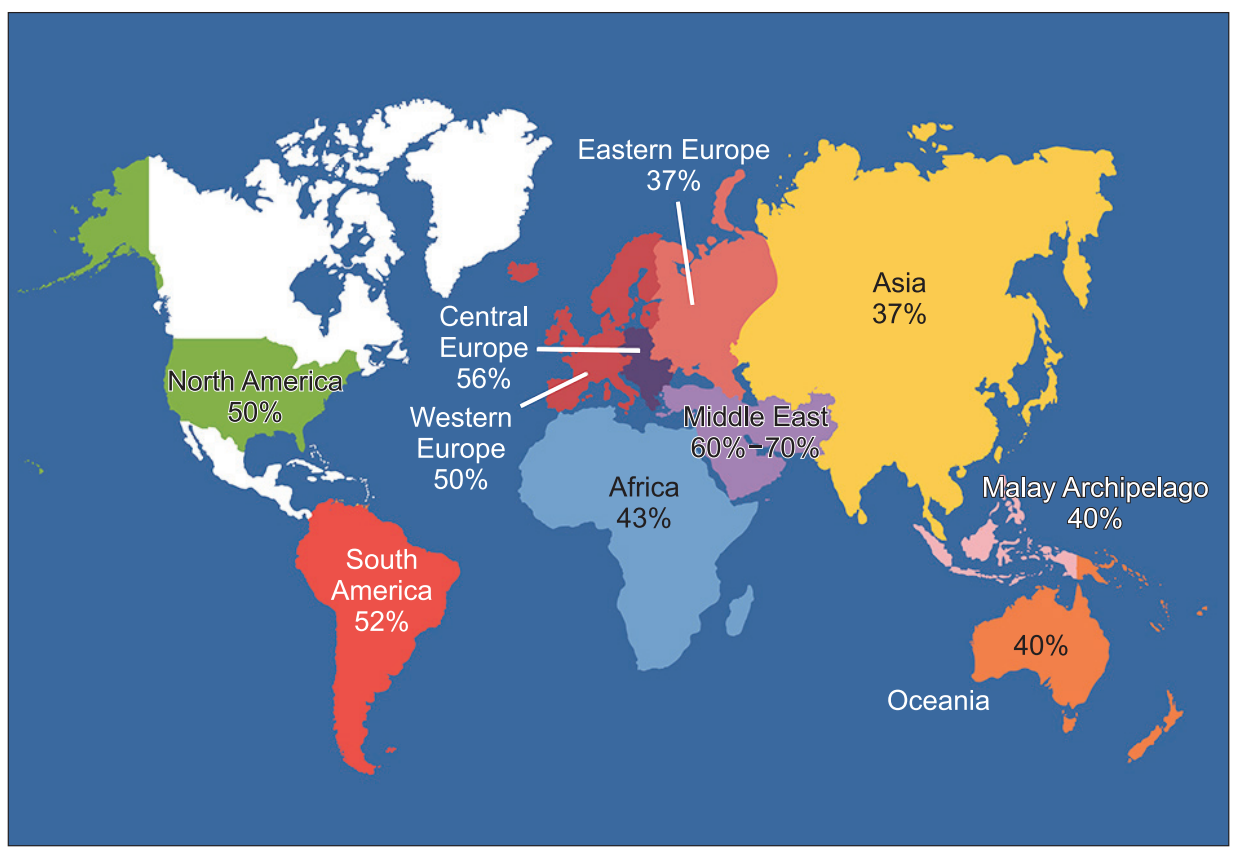

Fig. 1. World map containing percentages of infertility cases per region that are due to male factor involvement among regions studied. Asia includes all of Russia. Data from Agarwal et al (Reprod Biol Endocrinol 2015;13:37) [10]. 
idiopathic male infertility [20-22]. Unlike unexplained male infertility with its normal semen parameters, idiopathic male infertility is diagnosed in the presence of altered semen characteristics without an identifiable cause and the absence of female factor infertility [23].

\section{THE CONCEPT OF MALE OXIDATIVE STRESS INFERTILITY (MOSI)}

There is overwhelming evidence that oxidative stress (OS) plays a significant role in the etiology of male infertility [24-30]. Seminal reactive oxygen species (ROS) are produced mainly by leukocytes or abnormal and immature spermatozoa, and are a natural byproduct of oxidative metabolic pathways as well as cytosolic and plasma membrane oxidases [31-34]. ROS are also a natural byproduct of adenosine triphosphate production within sperm cell mitochondria [35]. Small quantities of ROS are required to ensure normal cellular physiological functions, including spermatogenesis and various sperm functions preceding fertilization, such as capacitation and acrosome reaction [32,36-38]. When ROS levels increase to a pathological level, the body uses dietary and endogenously produced antioxidants to bring the system back to homeostasis [39]. An imbalance between these two opposing forces, in which ROS outweigh antioxidants, can result in OS, which can negatively affect fertility via a number of pathways. OS interferes with capacitation and may cause sperm membrane and DNA damage, thereby affecting the sperm's potential to fertilize an egg and generate a healthy embryo [32,40-45]. Also, OS can trigger formation of genotoxic and mutagenic byproducts in the sperm that may increase the risk of disease in the offspring [46]. Depending on the assay methodology used, recent literature suggests that $30 \%$ to $80 \%$ of infertile men have elevated seminal ROS levels, a potentially treatable condition [28,30,44,47-56]. A similarly high incidence of OS was reported in a recent clinical trial, with $83.8 \%$ (124 of 148 cases) of idiopathic infertile men having positive seminal oxidation-reduction potential (ORP), a measure of ROS-antioxidant discrepancy [unpublished data].

Male reproductive potential cannot be adequately assessed if seminal OS is overlooked. However, there is currently no consensus concerning either the preferred method to measure OS in the clinical setting nor the diagnostic terminology to define this condition. Therefore, we propose the term Male Oxidative Stress Infertility, or MOSI, as a novel descriptor for infertile men with abnormal semen characteristics and OS, which includes many patients who were previously classified as having idiopathic male infertility (Appendix) [24,52,5759]. Based on several epidemiologic studies, OS may be present in about 56 million males complaining of infertility, two-thirds of whom are considered to have MOSI (https://www.nichd.nih.gov/health/topics/menshealth/ conditioninfo/infertility) (Fig. 3) [30,60-63]. In men with normal semen characteristics who are part of couples experiencing unexplained infertility, the role of OS is not well defined. In our experience, 29.4\% (10 of 34) of men in this group have leukocytospermia as opposed to

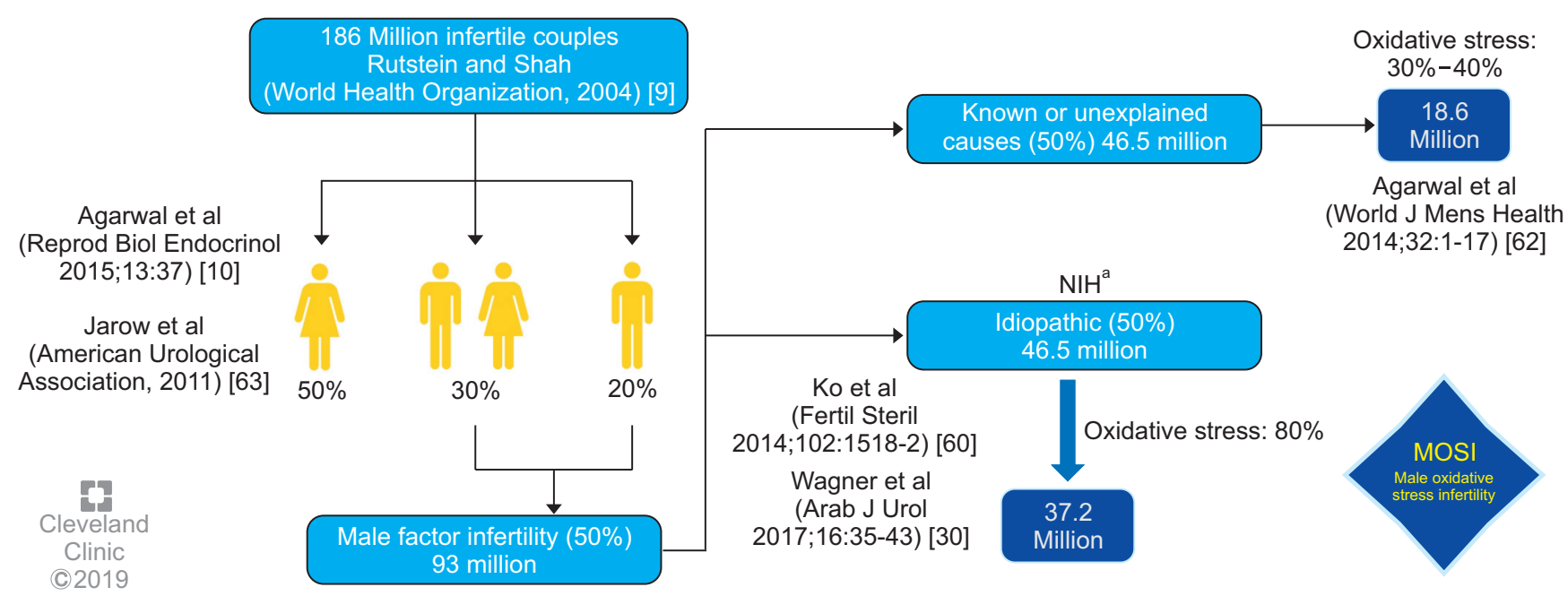

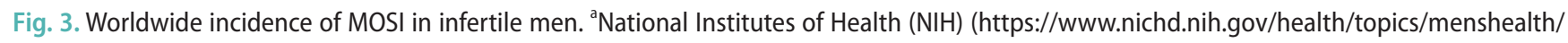
conditioninfo/infertility) [61], Agarwal et al (2014) [62], Jarow et al (2011) [63]. 
$12.2 \%$ (77 of 629 ) in the general population of men with infertility [unpublished data].

\section{DIAGNOSIS OF MALE OXIDATIVE STRESS INFERTILITY (MOSI)}

Conventional semen analysis was introduced about a century ago and remains the most widely used test for measuring sperm production and quality. In recent years, it has become clear that conventional semen analysis alone is not an adequate surrogate measure of male fecundity [64], as it is plagued with critical shortcomings such as poor reproducibility, subjectivity, and poor prediction of fertility [65-68]. Given the limited clinical utility of conventional semen analysis and the pathological consequences and ubiquity of OS among the subfertile male population, we propose the incorporation of ORP as a useful clinical biomarker for MOSI in men with abnormal semen analysis and male infertility [58,69-72]. ORP may be used to measure the levels of reductants (antioxidants) and oxidants in a variety of biological fluids [73] and could become an adjunct component of semen analysis due to its robust association with impaired sperm function. A number of assays are available to measure OS including chemilu- minescence for ROS, total antioxidant capacity for antioxidants, and the malondialdehyde assay for post-hoc damage from lipid peroxidation [74-76]. Though useful, these tests are difficult to incorporate into routine use because they are expensive, complex, and time-sensitive, and may also require complex instrumentation, large and neat sample volumes, and extensive technical training (Table 1) [76]. Additionally, assay results do not correlate with one another and provide only a single marker of OS-either oxidant levels, antioxidant levels, or post-hoc damage [77].

To date, measurement of ROS in semen is not often utilized as, depending on the method for ROS assessment, it may be prone to intra- and inter-laboratory variability, high turnaround time and high costs $[58,69,78]$. The advent of new technologies that rapidly detect seminal OS through the assessment of ORP in a reproducible manner using a bench-top analyzer can allow for an accurate and cost-effective diagnosis of MOSI [76,78,79]. The Male Infertility Oxidative System (MiOXSYS) is a recently developed assay for the assessment of ORP [69]. The ORP test is novel in the area of infertility and is based on a galvanostatic measure of electrons. MiOXSYS has been developed for easy and quick measurement of ORP in semen [80]. Several

Table 1. Advantages and disadvantages of commonly used techniques to measure seminal oxidative stress

\begin{tabular}{|c|c|c|}
\hline Assay & Advantages & Disadvantages \\
\hline ROS by chemiluminescence & $\begin{array}{l}\text { - Chemiluminescence is robust } \\
\text { - High sensitivity and specificity } \\
\text { - Luminol measures global ROS levels - both } \\
\text { extracellular and intracellular (superoxide anion, } \\
\text { hydrogen peroxide, hydroxyl radical) }\end{array}$ & $\begin{array}{l}\text { - Time-consuming method } \\
\text { - Requires large and expensive equipment } \\
\text { - Variables such as semen age, volume, repeated } \\
\text { centrifugation, temperature control and background } \\
\text { luminescence may interfere with measurement }\end{array}$ \\
\hline TAC & $\begin{array}{l}\text { - Rapid colorimetric method } \\
\text { - Measures total antioxidants in seminal plasma }\end{array}$ & $\begin{array}{l}\text { - Does not measure enzymatic antioxidants } \\
\text { - Length of inhibition time is a critical aspect of the test } \\
\text { - Requires expensive microplate readers }\end{array}$ \\
\hline ROS-TAC score & - Better predictor compared with ROS or TAC alone & $\begin{array}{l}\text { - Requires statistical modeling } \\
\text { - Not a direct measure of ROS or TAC, rather a prediction } \\
\text { of oxidative stress }\end{array}$ \\
\hline $\begin{array}{l}\text { MDA-TBA adduct detection } \\
\text { by colorimetry or } \\
\text { fluoroscopy }\end{array}$ & $\begin{array}{l}\text { - Measures lipid peroxidation } \\
\text { - Detects MDA-TBA adduct by colorimetry or } \\
\text { fluoroscopy }\end{array}$ & $\begin{array}{l}\text { - Rigorous controls required } \\
\text { - Non-specific test providing post hoc measure only }\end{array}$ \\
\hline ORP & $\begin{array}{l}\text { - Provides redox balance in real time } \\
\text { - Measures all known and unknown oxidants and } \\
\text { antioxidants } \\
\text { - Less time-consuming and requires less expertise } \\
\text { - Can be measured in semen and seminal plasma, } \\
\text { including frozen specimens }\end{array}$ & - Affected by viscosity of the sample \\
\hline
\end{tabular}

Data from Agarwal et al (Ther Adv Urol 2016;8:302-18) [76].

ROS: reactive oxygen species, TAC: total antioxidant capacity, MDA: malondialdehyde, TBA: thiobarbituric acid, ORP: oxidation-reduction potential. 
studies have validated the reproducibility and reliability of the MiOXSYS in measuring ORP levels in semen samples from patients being evaluated for male infertility [58,69,71,81]. More importantly, ORP levels have been shown to be significantly negatively correlated with sperm concentration, sperm motility, normal morphology and total motile count [72]. ORP levels are also significantly positively correlated with sperm DNA fragmentation (SDF) [72,79,81], although normal levels of SDF do not exclude the presence of OS. At a cutoff value of $1.34\left(\mathrm{mV} / 10^{6} \mathrm{sperm} / \mathrm{mL}\right)$, ORP may be used to differentiate between normal and abnormal semen quality in infertile men with $98.1 \%$ sensitivity, $40.6 \%$ specificity, $94.7 \%$ positive predictive value, and $66.6 \%$ negative predictive value [58,59,69] (Fig. 4).

Among infertile men, higher ORP levels are observed in cases with abnormal semen parameters versus normal parameters (Fig. 5A, 5B). Analysis of data of 3,966 patients at Hamad Medical Corporation, Doha, Qatar, revealed statistically significant negative correlations between ORP and normal sperm morphology $(r=0.529$, $\mathrm{p}<0.0001)$, progressive motility $(\mathrm{r}=-0.463, \mathrm{p}<0.0001)$, and sperm concentration $(r=-0.844, \mathrm{p}<0.0001)$. The difference in ORP between normozoospermic (mean: $1.14 \pm 0.97$ $\mathrm{mV} / 10^{6}$ sperm $/ \mathrm{mL}$; median: $0.86 \mathrm{mV} / 10^{6}$ sperm $/ \mathrm{mL}$ ) and non-normozoospermic (mean: $5.65 \pm 11.34 \mathrm{mV} / 10^{6} \mathrm{sperm} /$ $\mathrm{mL}$; median: $2.04 \mathrm{mV} / 10^{6} \mathrm{sperm} / \mathrm{mL}$ ) patients was also significant $(p<0.0001)$ (Fig. $5 B)$. Fig. $5 \mathrm{C}$ depicts ORP
A

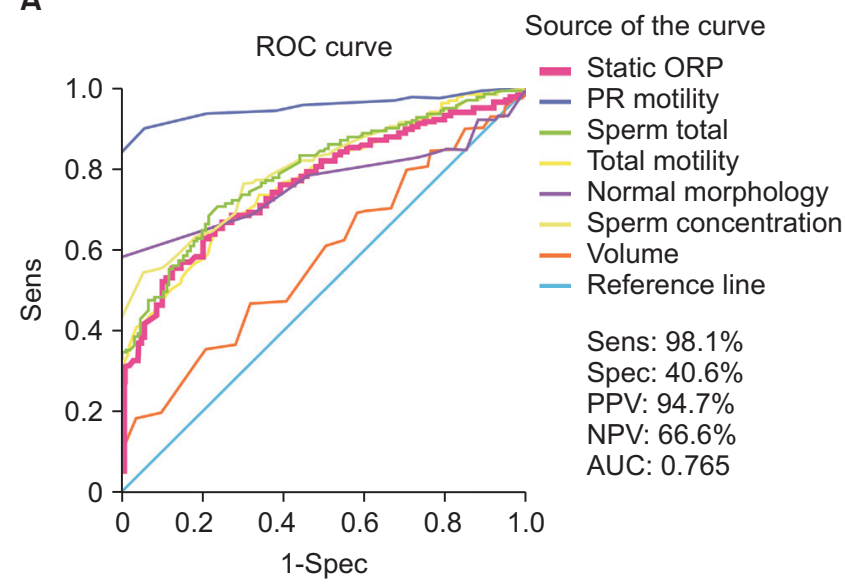

B

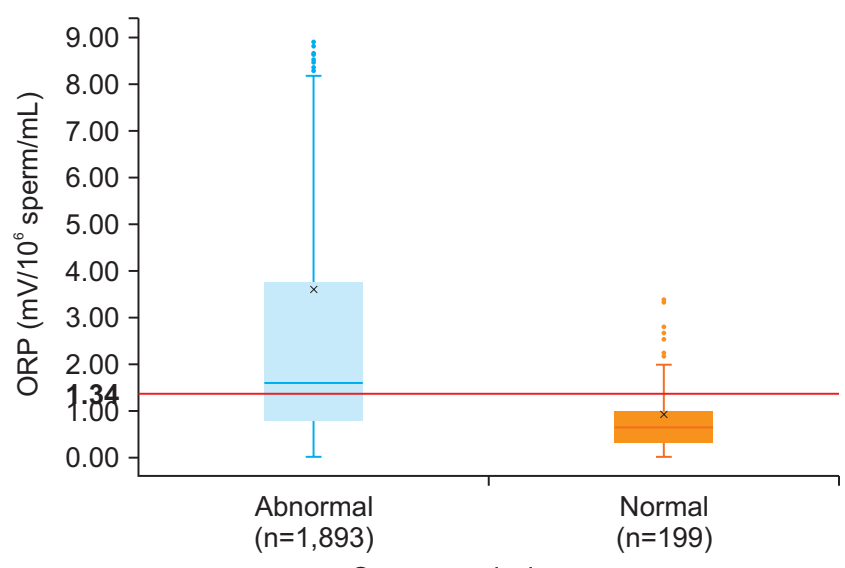

Fig. 4. (A) A receiver operating characteristic (ROC) curve was used to identify the oxidation-reduction potential (ORP) (mV/10 $\mathrm{sperm} / \mathrm{mL}) \mathrm{cutoff}$ that best predicted normal and abnormal semen parameters based on sensitivity (Sens), specificity (Spec), positive predictive value (PPV), negative predictive value (NPV), and area under the curve (AUC). (B) Distribution of ORP in patients with at least one abnormal semen parameter versus patients with normal semen parameters, showing the established cutoff value of $1.34 \mathrm{mV} / 10^{6} \mathrm{sperm} / \mathrm{mL}$. Data from Agarwal et al (Asian J Androl 2019 [Epub]) [59].
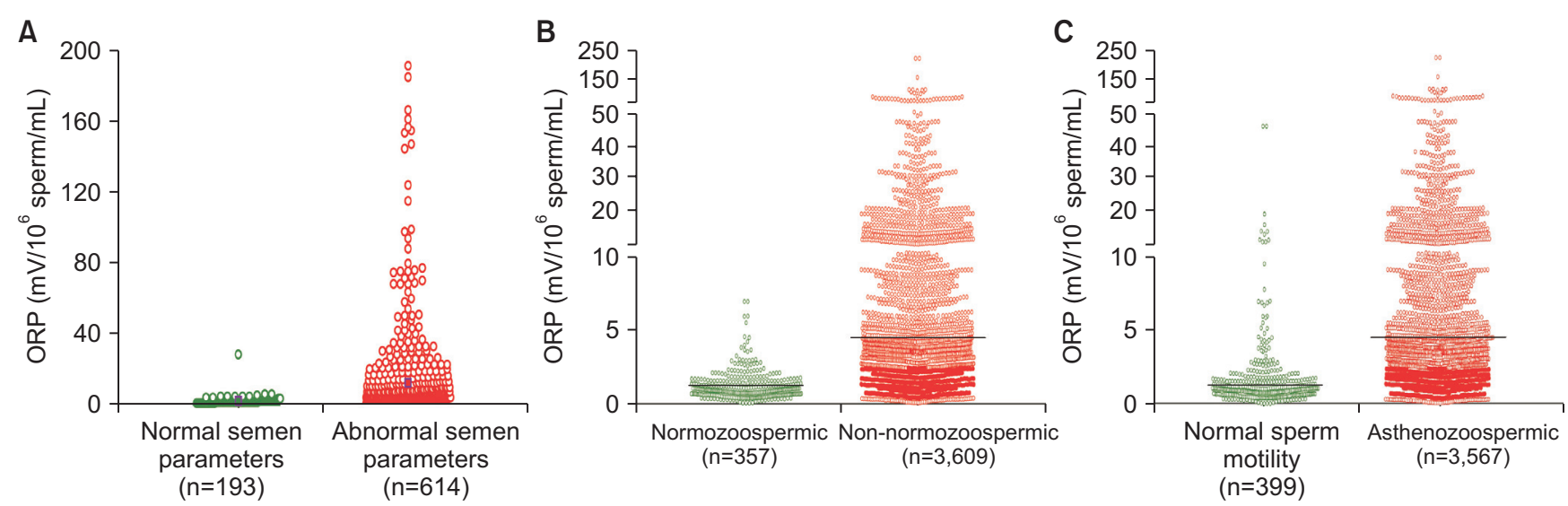

Fig. 5. Distribution of oxidation-reduction potential (ORP) values in the infertile men with normal and abnormal semen parameters. (A) Data from Cleveland Clinic, Cleveland OH, USA ( $n=807)$; (B) Data from Hamad Medical Corporation, Doha, Qatar ( $n=3,966)$; (C) Data of asthenozoospermic patients from Hamad Medical Corporation, Doha, Qatar $(n=3,966)$. 
values of asthenozoospermic (mean: $5.63 \pm 11.36 \mathrm{mV} / 10^{6}$ sperm $/ \mathrm{mL}$; median: $2.03 \mathrm{mV} / 10^{6}$ sperm $\left./ \mathrm{mL}\right)$ versus nonasthenozoospermic patients (mean: $1.79 \pm 3.80 \mathrm{mV} / 10^{6}$ sperm/mL; median: $0.92 \mathrm{mV} / 10^{6}$ sperm $/ \mathrm{mL}$ ) [unpublished data].

\section{MANAGEMENT AND TREATMENT OF MALE OXIDATIVE STRESS INFERTILITY (MOSI)}

Despite significant advances in the diagnosis and management of male infertility, there are no evidencebased treatment guidelines available for idiopathic male infertility. Understandably, it is difficult to develop an evidence-based approach for a condition with an unclear etiology. A survey among members of the American Urological Association (AUA) indicated that two-thirds of clinicians use empirical medical therapy (EMT) such as selective estrogen receptor modulators, aromatase inhibitors, and gonadotropins to treat idiopathic male factor infertility [82]. While the role of hormonal therapy in men with an identified abnormality such as hypogonadotropic hypogonadism is well-defined [83], endocrine imbalance is responsible for approximately $10 \%$ of all known causes of infertility [21]. The literature remains inconclusive and controver-

Table 2. Empiric medical treatment for idiopathic male infertility (ICD10 Code: Z31.41)

\begin{tabular}{|c|c|c|c|c|}
\hline Medication & Administration & $\begin{array}{l}\text { Common } \\
\text { dosages }\end{array}$ & Adverse effects & $\begin{array}{l}\text { Estimated cost } \\
\text { per } 3 \text { months }\end{array}$ \\
\hline \multicolumn{5}{|c|}{ Selective estrogen receptor modulators } \\
\hline Clomiphene citrate ${ }^{\mathrm{a}}$ & Oral & 50 mg daily & $\begin{array}{l}\text { Hot flashes, weight gain, gynecomastia, hair } \\
\text { loss, dizziness, gastrointestinal distress }\end{array}$ & $\$ 185.40^{c}$ \\
\hline Tamoxifen citrate ${ }^{a}$ & Oral & 20 mg daily & See above & $\$ 99.60^{c}$ \\
\hline \multicolumn{5}{|l|}{ Aromatase inhibitors } \\
\hline Anastrozole $\mathrm{e}^{\mathrm{a}}$ & Oral & $1 \mathrm{mg}, 3$ times/wk & $\begin{array}{l}\text { Decreased libido, headache, elevated liver } \\
\text { function tests }\end{array}$ & $\$ 35.40^{c}$ \\
\hline $\begin{array}{l}\text { Human chorionic- } \\
\text { gonadotropin }^{\text {b }}\end{array}$ & Subcutaneous & $\begin{array}{l}1,500-3,000 \text { IU, } \\
3 \text { times/wk }\end{array}$ & $\begin{array}{l}\text { Injection site pain, headache, depression, } \\
\text { gynecomastia, hyperglycemia }\end{array}$ & $\$ 337.50-\$ 675.00^{d}$ \\
\hline $\begin{array}{l}\text { Recombinant follicle- } \\
\text { stimulating hormone }^{b}\end{array}$ & Subcutaneous & 75 IU, 3 times/wk & Injection site pain & $\$ 2,160.00^{d}$ \\
\hline
\end{tabular}

${ }^{\mathrm{a} O f f}$ label use; ${ }^{\mathrm{b}}$ Food and Drug Administration approved for treatment of infertility secondary to gonadotropin deficiency; ${ }^{\mathrm{c} A v e r a g e}$ cost at Walmart, CVS and Walgreens; ${ }^{\mathrm{d} C o m p o u n d}$ pharmacy cost.

Table 3. Antioxidant classification in relation to its action on sperm characteristics

\begin{tabular}{|c|c|c|}
\hline Type & Function & References \\
\hline \multicolumn{3}{|l|}{ Enzymatic: } \\
\hline Superoxide dismutase & First line defense antioxidants & {$[94,95]$} \\
\hline Catalase & First line defense antioxidants & {$[54,96]$} \\
\hline Glutathione peroxidase & Scavenges lipid peroxides and hydrogen peroxide & {$[97,98]$} \\
\hline Glutathione reductase & Scavenges lipid peroxides and hydrogen peroxide & [99] \\
\hline \multicolumn{3}{|l|}{ Non enzymatic: } \\
\hline Vitamin C & Neutralizes free radicals & {$[100,101]$} \\
\hline Vitamin E & Neutralizes free radicals & {$[102,103]$} \\
\hline Ferritin and carnitines & Neutralizes free radicals and acts as an energy source & [126] \\
\hline Coenzyme Q10 & In its reduced form, scavenges free radicals intermediate in mitochondrial electron transport system & [104] \\
\hline Transferrin & Sperm vitality, DNA integrity and OS homeostasis & [105] \\
\hline Zinc & Formation of free oxygen radicals and sperm chromatin stability & [106] \\
\hline Selenium & Sperm motility and OS homeostasis & {$[107]$} \\
\hline $\mathrm{N}$-acetyl L-cysteine & Free radical scavenging activity & {$[108,109]$} \\
\hline L-arginine & Formation of free oxygen radicals & [110] \\
\hline Folic acid & Sperm DNA integrity & [111] \\
\hline
\end{tabular}

OS: oxidative stress. 
sial regarding off-label EMTs for men with idiopathic infertility [20,82,84-87], especially in light of their cost and side effects (Table 2). Although there are several small studies that provide support for pharmacological EMT to treat idiopathic male infertility, there is a lack of robust placebo-controlled trials demonstrating improved live birth outcomes [87-90].

For the vast majority of infertile men with no underlying endocrine, bacterial, genetic or anatomical causes of infertility, an alternative approach may be to shift from administering EMTs to identifying potential sources of MOSI and mitigating the sequela. The human body produces endogenous antioxidants in an ef- fort to prevent the damage caused by ROS [91,92], but this response is not always adequate, resulting in OS. Several studies have shown that exogenous antioxidants have the capacity to counteract oxidative damage or OS, improving both sperm motility and DNA integrity for infertile men with OS (Table 3) [87-91,93111]. Indeed, many oral formulations of antioxidants are readily available in the market and are commonly used to treat men with infertility. However, there is growing awareness that the indiscriminate use of antioxidants may paradoxically exacerbate sperm cell damage in men without elevated MOSI by inducing a state of reductive stress [52,112]. In order to prevent

Table 4. Effect of antioxidants on male infertility: Double blind placebo controlled studies ${ }^{\mathrm{a}}$

\begin{tabular}{|c|c|c|c|c|c|}
\hline Study reference & Infertility type & Cases & Antioxidants & Duration & Outcome \\
\hline $\begin{array}{l}\text { Micic et al } \\
\text { (2019) [119] }\end{array}$ & $\begin{array}{l}\text { Idiopathic oligo- } \\
\text { asthenozoo- } \\
\text { spermia }\end{array}$ & $\begin{array}{l}\text { Placebo group }(n=50) \\
\text { Treatment group } \\
\quad(n=125)\end{array}$ & $\begin{array}{l}\text { Proxeed plus }=2 \text { times } / \mathrm{d} \\
\text { - } \mathrm{LC}=1,000 \mathrm{~g}, \mathrm{LAC}=0.5 \mathrm{~g} \text {, } \\
\text { fumarate }=0.725 \mathrm{~g} \text {, fructose }=1 \mathrm{~g} \text {, } \\
\text { citric acid }=50 \mathrm{mg}, \text { zinc }=10 \mathrm{mg}, \\
\text { coenzyme } \mathrm{Q} 10=20 \mathrm{mg}, \\
\text { selenium }=50 \mu \mathrm{g}, \text { Vit } C=90 \mathrm{mg}, \\
\text { folic acid }=200 \mu \mathrm{g}, \text { Vit B12=1.5 } \mu \mathrm{g}\end{array}$ & 3 months & $\begin{array}{l}\text { Increase in semen } \\
\text { volume, progressive } \\
\text { motility and vitality } \\
\text { Decrease in sperm } \\
\text { DNA fragmentation } \\
\text { index }\end{array}$ \\
\hline $\begin{array}{l}\text { Busetto et al } \\
\text { (2018) [113] }\end{array}$ & $\begin{array}{l}\text { Idiopathic OAT, } \\
\text { with and with- } \\
\text { out varicocele }\end{array}$ & $\begin{array}{l}\text { Varicocele }(n=45) \\
\text { Without varicocele } \\
\quad(n=49)\end{array}$ & $\begin{array}{l}\mathrm{LC}=1,000 \mathrm{mg}, \mathrm{LAC}=500 \mathrm{mg}, \\
\text { fumarate }=725 \mathrm{mg}, \text { fructose }= \\
1,000 \mathrm{mg}, \text { Coenzyme } \mathrm{Q} 10=20 \\
\mathrm{mg}, \mathrm{Vit} \mathrm{C}=90 \mathrm{mg}, \text { Zinc }=10 \mathrm{mg}, \\
\text { folic acid }=200 \mu \mathrm{g}, \text { Vit B12 }=1.5 \mu \mathrm{g}\end{array}$ & 6 months & $\begin{array}{l}\text { Increase in sperm } \\
\text { concentration, total } \\
\text { sperm count, motil- } \\
\text { ity, and progressive } \\
\text { motility }\end{array}$ \\
\hline $\begin{array}{l}\text { Safarinejad et al } \\
\text { (2012) [116] }\end{array}$ & $\begin{array}{l}\text { Idiopathic } \\
\text { infertility }\end{array}$ & $\begin{array}{l}\text { Placebo group }(n=114) \\
\text { Treatment group } \\
\quad(n=114)\end{array}$ & Coenzyme Q10=200 mg/d & 26 weeks & $\begin{array}{l}\text { Increase in sperm } \\
\text { concentration, } \\
\text { motility and normal } \\
\text { sperm morphology }\end{array}$ \\
\hline $\begin{array}{l}\text { Safarinejad } \\
\text { (2009) [114] }\end{array}$ & Idiopathic OAT & $\begin{array}{l}\text { Placebo group }(n=106) \\
\text { Treatment group } \\
\quad(n=106)\end{array}$ & Coenzyme Q10=300 mg/d & 26 weeks & $\begin{array}{l}\text { Increase in sperm } \\
\text { concentration and } \\
\text { motility }\end{array}$ \\
\hline $\begin{array}{l}\text { Balercia et al } \\
\text { (2009) [120] }\end{array}$ & $\begin{array}{l}\text { Idiopathic } \\
\text { asthenozoo- } \\
\text { spermia }\end{array}$ & $\begin{array}{l}\text { Placebo group }(n=30) \\
\text { Treatment group }(n=30)\end{array}$ & Coenzyme Q10=200 mg/d & 3 months & $\begin{array}{l}\text { Increase in sperm } \\
\text { concentration and } \\
\text { motility }\end{array}$ \\
\hline $\begin{array}{l}\text { Tremellen et al } \\
\text { (2008) [28] }\end{array}$ & $\begin{array}{l}\text { Male factor } \\
\text { infertility }\end{array}$ & $\begin{array}{l}\text { Placebo group }(n=20) \\
\text { Infertile men }(n=40)\end{array}$ & $\begin{array}{l}\text { Menevit=1 capsule/d } \\
\text { - Lycopene=6 mg, Vit E=400 IU, } \\
\text { Vit } C=100 \text { mg, Zinc=25 mg, } \\
\text { selenium }=26 \mu \text {, folate=0.5 } \\
\text { mg, garlic- } 1,000 \text { mg, palm oil } \\
\text { (vehicle) }\end{array}$ & 3 months & $\begin{array}{l}\text { Improved pregnancy } \\
\text { rates in couples } \\
\text { undergoing IVF-ICSI } \\
\text { treatment for severe } \\
\text { male factor infertility }\end{array}$ \\
\hline $\begin{array}{l}\text { Balercia et al } \\
\text { (2005) [115] }\end{array}$ & $\begin{array}{l}\text { Idiopathic } \\
\text { asthenozoo- } \\
\text { spermia }\end{array}$ & $\begin{array}{l}\text { Placebo group }(n=15) \\
\text { Treatment group } \\
\text { ( } n=45) \text { : } \\
\text { LC group: } n=15 ; \\
\text { LAC group: } n=15 ; \\
\text { LC+LAC group: } n=15\end{array}$ & $\begin{array}{l}\mathrm{LC}=3 \mathrm{~g} / \mathrm{d} \\
\mathrm{LAC}=3 \mathrm{~g} / \mathrm{d} \\
\mathrm{LC}+\mathrm{LAC}=2 \mathrm{~g}+1 \mathrm{~g} / \mathrm{d}\end{array}$ & 6 months & $\begin{array}{l}\text { Increase in sperm } \\
\text { motility and normal } \\
\text { sperm morphology }\end{array}$ \\
\hline
\end{tabular}

OAT: oligoasthenoteratozoospermia, LC: L-carnitine, LAC: L-acetylcarnitine, Vit: vitamin, IVF-ICSI: in vitro fertilization/intracytoplasmic sperm injection.

${ }^{a}$ Only double blind placebo control studies on idiopathic male infertility patients were included. Except for three studies (94, 96, and 142), others used a combination of antioxidant supplements for a period of 3 to 6 months. 
the inappropriate use of antioxidants, clinical guidelines outlining the effective diagnosis and treatment of MOSI are critical. Several clinical trials and systemic reviews involving the use of various combinations of antioxidants (L-carnitine, selenium, N-acetyl-cysteine, Coenzyme Q10, ubiquinol, vitamin E, vitamin C, and lycopene) in infertile men have reported beneficial effects of antioxidants on sperm concentration, motility, and DNA integrity (Table 4) [113-120]. Preliminary results from a 2018 clinical trial involving 148 idiopathic infertile men indicated that intake of oral antioxidants for a period of three months significantly increased sperm concentration $(36 \%, \mathrm{p}<0.0001)$, progressive motility $(100 \%, \mathrm{p}<0.0001)$, and motility $(12 \%, \mathrm{p}=0.0033)$. Moreover, a significant decrease in ORP $(39 \%, \mathrm{p}<0.0001)$ and SDF (20\%, $\mathrm{p}=0.0002)$ was observed post-treatment [unpublished data]. These beneficial changes in semen quality have been reported to improve the chance of natural conception in several but not all studies [53,121]. This benefit could be augmented, and harm prevented, by directing therapy through measuring and monitoring seminal ORP [113-116,122,123].

Identifying and treating MOSI in cases where the use of assisted reproductive technology (ART) is indicated is especially important, as many of the sperm preparation and handling methods used during ART may induce OS, further aggravating the negative impact of MOSI [124,125]. In couples undergoing ART, diagnosis of MOSI and subsequent antioxidant therapy may improve ART success [122,126,127]. Additionally, there is emerging evidence that antioxidant therapy may improve pregnancy outcomes in couples with recurrent pregnancy loss [128]. Evidence-based guidelines should provide recommendations on ways to best manage other causes of OS, including lifestyle modifications (improved diet, smoking cessation, exercise, and weight loss), treatment of clinically relevant varicoceles, and treatment of male accessory gland infection (MAGI) as well as other inflammatory pathologies linked with MOSI (Fig. 3). The treatment of MAGI with antibiotics, and the decrease in the numbers of ROS-producing seminal leukocytes using anti-inflammatories are likely to add benefit in combination with neutralization of ROS by antioxidant therapy [129-132]. Treatment success and adherence for the above conditions can be monitored by measuring seminal ORP, as well.

The diagnosis and management of idiopathic male infertility is an integral component of comprehensive sexual and reproductive health services. Idiopathic male infertility can be an emotional burden and financial strain for couples. Current treatment protocols for male infertility are not evidence-based and have the potential risk of complications and increased healthcare-related expenditures [20,84]. MOSI provides clinicians and patients with a diagnostic classification to guide future research and treatment, while simultaneously reducing apprehension and uncertainty for many couples. A recent consensus guideline by the Eu-

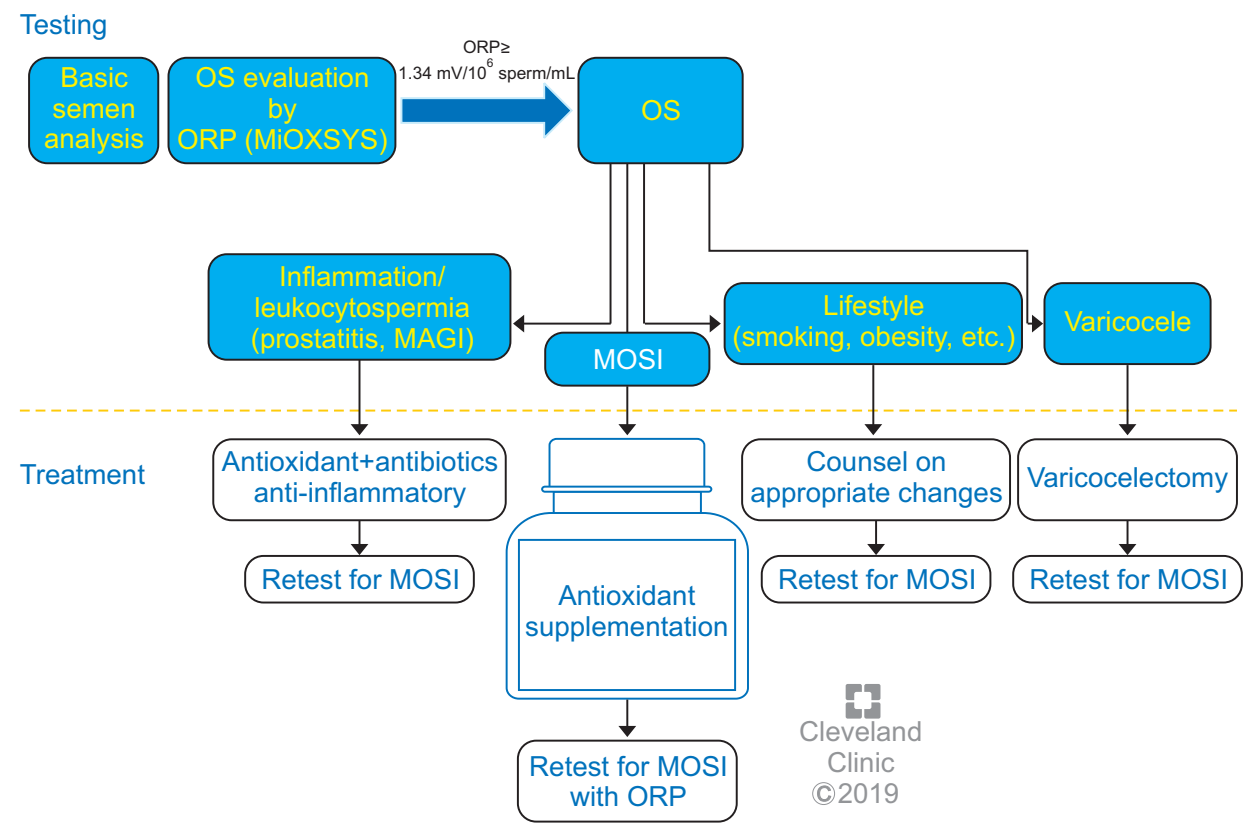

Fig. 6. Treatment options for male oxidative stress infertility. OS: oxidative stress, ORP: oxidation-reduction potential, MiOXSYS: Male Infertility Oxidative System, MAGI: male accessory gland infection, MOSI: Male Oxidative Stress Infertility. 
ropean Society for Human Reproduction \& Embryology (ESHRE) concluded that there is currently insufficient evidence to support the use of antioxidants for male infertility due to lack of a standardized measure of OS and inconsistent selection of eligible patients across studies [133]. MOSI diagnosis combined with ORP monitoring may provide a more targeted, reliable approach for using antioxidant therapy in both research and practice.

Compared with hormonal EMT and ART, antioxidants are relatively safe, inexpensive and widely available, with a growing body of data supporting their effectiveness at improving semen parameters and live birth rates [53]. Further clinical studies are indicated to directly compare live birth rates among men with MOSI assigned to receive antioxidants versus EMT and ART. Treatment guidelines providing individualized antioxidant therapy protocols based on ORP status for men with MOSI could provide a significant advancement in the management of male factor infertility and facilitate future investigations (Fig. 6) [134]. Guidelines are also necessary to avoid possible overuse of antioxidants leading to reductive stress, which can be as detrimental to sperm health as OS [52,135-137] and has been associated with defects in embryogenesis [138]. Supra-physiologic levels of antioxidants may also scavenge the ROS necessary to induce sperm capacitation [32,38], leading to infertility. Because antioxidants are readily available online or over-the-counter, they may appear to be a benign first-line treatment. Without clear guidelines for appropriate use, however, there is a risk of overuse in men without evidence of MOSI who may then experience delay accessing more effective therapies (e.g., ART or varicocele repair). Therefore, the oxidative status of male infertility patients should be evaluated before antioxidants are recommended and used only in those cases where MOSI is present.

\section{RECOMMENDATIONS AND FUTURE DIRECTIONS}

Therefore, the authors recommend that men with idiopathic infertility should be screened for MOSI using an efficient, inexpensive, high sensitivity/specificity test for ORP such as MiOXSYS, which has practical advantages over alternative techniques (Table 1). Those men screening positive for MOSI should then undergo more extensive examination to identify treat- able triggers and be counseled on appropriate steps to mitigate known causes of OS (e.g., smoking, alcohol consumption, lifestyle risk factors, radiation, toxins, etc.) $[139,140]$. ORP testing should be repeated no less than 3 months following the appropriate management plan in infertile men with no explanation for MOSI. Ultimately, infertile men with MOSI should be advised to take antioxidants for a minimum of three months after other known causes of OS have been eliminated. Infertile men without MOSI should be advised against antioxidant therapy. Follow-up testing of ORP levels is recommended to confirm compliance and monitor the efficacy of antioxidant supplementation and continued lifestyle changes 6 to 8 weeks post treatment. We recommend that these approaches be tested in double blind randomized controlled trials to establish whether time to pregnancy and live birth rate is improved in couples where the man is undergoing antioxidant treatment.

With the increasing awareness and understanding of MOSI as a distinct male infertility diagnosis, the development of evidence-based guidelines that target the underlying causes, while balancing the risks and benefits of individual therapies, is imperative. The authors feel that measurement of ORP and stratification of male fertility/infertility on the basis of ORP will be an important tool in the management of infertile couples. The exact role will be defined in future trials and could validate a reclassification of male infertility that incorporates MOSI as a diagnostic category. A better understanding of the etiology of this diagnosis will help identify those men likely to benefit from antioxidant therapy while minimizing the harmful effects of antioxidant overdosing.

\section{ACKNOWLEDGEMENTS}

The authors thank Ken Kula, Mary Reagan, and Bernastine Buchanan from the Center for Medical Art and Photography for assistance with the figures.

Financial support for this study was provided by the American Center for Reproductive Medicine.

\section{Disclosure}

None of the authors declares competing financial interests. The authors do not have any potential interest in promoting MiOXSYS. 


\section{Author Contribution}

Conceptualization: AA. Writing-original draft: NP, AA, MKPS. Writing-review \& editing: all the authors.

\section{REFERENCES}

1. Thoma ME, McLain AC, Louis JF, King RB, Trumble AC, Sundaram R, et al. Prevalence of infertility in the United States as estimated by the current duration approach and a traditional constructed approach. Fertil Steril 2013;99:132431.e1.

2. Kassa EM, Kebede E. Time-to-pregnancy and associated factors among couples with natural planned conception in Addis Ababa, Ethiopia. Afr J Reprod Health 2018;22:33-42.

3. Slama R, Hansen OK, Ducot B, Bohet A, Sorensen D, Giorgis Allemand L, et al. Estimation of the frequency of involuntary infertility on a nation-wide basis. Hum Reprod 2012;27: 1489-98.

4. Juul S, Karmaus W, Olsen J. Regional differences in waiting time to pregnancy: pregnancy-based surveys from Denmark, France, Germany, Italy and Sweden. Hum Reprod 1999;14: 1250-4.

5. Zinaman MJ, Clegg ED, Brown CC, O'Connor J, Selevan SG. Estimates of human fertility and pregnancy loss. Fertil Steril 1996;65:503-9.

6. Zegers-Hochschild F, Adamson GD, Dyer S, Racowsky C, de Mouzon J, Sokol R, et al. The international glossary on infertility and fertility care, 2017. Fertil Steril 2017;108:393-406.

7. Practice Committee of American Society for Reproductive Medicine. Definitions of infertility and recurrent pregnancy loss: a committee opinion. Fertil Steril 2013;99:63.

8. Inhorn MC, Patrizio P. Infertility around the globe: new thinking on gender, reproductive technologies and global movements in the 21st century. Hum Reprod Update 2015; 21:411-26.

9. Rutstein SO, Shah IH; ORC Macro; World Health Organization. Infecundity, infertility, and childlessness in developing countries. Calverton: World Health Organization; 2004.

10. Agarwal A, Mulgund A, Hamada A, Chyatte MR. A unique view on male infertility around the globe. Reprod Biol Endocrinol 2015;13:37.

11. World Health Organization. WHO laboratory manual for the examination and processing of human semen. Geneva: World Health Organization; 2010.

12. Irvine DS. Epidemiology and aetiology of male infertility. Hum Reprod 1998;13 Suppl 1:33-44.

13. O'Flynn O'Brien KL, Varghese AC, Agarwal A. The genetic causes of male factor infertility: a review. Fertil Steril 2010; 93:1-12.

14. Sharma R, Biedenharn KR, Fedor JM, Agarwal A. Lifestyle factors and reproductive health: taking control of your fertility. Reprod Biol Endocrinol 2013;11:66.

15. Jurewicz J, Dziewirska E, Radwan M, Hanke W. Air pollution from natural and anthropic sources and male fertility. Reprod Biol Endocrinol 2018;16:109.

16. Punab M, Poolamets O, Paju P, Vihljajev V, Pomm K, Ladva $\mathrm{R}$, et al. Causes of male infertility: a 9-year prospective monocentre study on 1737 patients with reduced total sperm counts. Hum Reprod 2017;32:18-31.

17. Tournaye H, Krausz C, Oates RD. Novel concepts in the aetiology of male reproductive impairment. Lancet Diabetes Endocrinol 2017;5:544-53.

18. Gabrielsen JS, Tanrikut C. Chronic exposures and male fertility: the impacts of environment, diet, and drug use on spermatogenesis. Andrology 2016;4:648-61.

19. Pasqualotto FF, Pasqualotto EB, Sobreiro BP, Hallak J, Medeiros F, Lucon AM. Clinical diagnosis in men undergoing infertility investigation in a university hospital. Urol Int 2006;76:122-5.

20. Chehab M, Madala A, Trussell JC. On-label and off-label drugs used in the treatment of male infertility. Fertil Steril 2015;103:595-604.

21. Jungwirth A, Diemer T, Kopa Z, Krausz C, Minhas S, Tournaye $\mathrm{H}$. EAU guidelines on male infertility. Arnhem: European Association of Urology; 2018.

22. de Kretser DM. Male infertility. Lancet 1997;349:787-90.

23. Hamada A, Esteves SC, Agarwal A. Unexplained male infertility: potential causes and management. Hum Androl 2011; 1:2-16.

24. Agarwal A, Durairajanayagam D, Halabi J, Peng J, VazquezLevin M. Proteomics, oxidative stress and male infertility. Reprod Biomed Online 2014;29:32-58.

25. Aitken RJ. Oxidative stress and the etiology of male infertility. J Assist Reprod Genet 2016;33:1691-2.

26. Bui AD, Sharma R, Henkel R, Agarwal A. Reactive oxygen species impact on sperm DNA and its role in male infertility. Andrologia 2018;50:e13012.

27. Agarwal A, Sharma RK, Nallella KP, Thomas AJ Jr, Alvarez JG, Sikka SC. Reactive oxygen species as an independent marker of male factor infertility. Fertil Steril 2006;86:878-85.

28. Tremellen K. Oxidative stress and male infertility: a clinical perspective. Hum Reprod Update 2008;14:243-58.

29. Aitken RJ, De Iuliis GN, Drevet JR. Role of oxidative stress in the etiology of male infertility and the potential therapeutic value of antioxidants. In: Henkel R, Samanta L, Agarwal 
A, editors. Oxidants, antioxidants, and impact of the oxidative status in male reproduction. London: Elsevier/Academic Press; 2018;91-100.

30. Wagner H, Cheng JW, Ko EY. Role of reactive oxygen species in male infertility: an updated review of literature. Arab J Urol 2017;16:35-43.

31. Sharma RK, Agarwal A. Role of reactive oxygen species in male infertility. Urology 1996;48:835-50.

32. Aitken RJ. Reactive oxygen species as mediators of sperm capacitation and pathological damage. Mol Reprod Dev 2017; 84:1039-52.

33. Robinson JM. Phagocytic leukocytes and reactive oxygen species. Histochem Cell Biol 2009;131:465-9.

34. Aitken RJ, West K, Buckingham D. Leukocytic infiltration into the human ejaculate and its association with semen quality, oxidative stress, and sperm function. J Androl 1994; 15:343-52.

35. Cassina A, Silveira P, Cantu L, Montes JM, Radi R, Sapiro R. Defective human sperm cells are associated with mitochondrial dysfunction and oxidant production. Biol Reprod 2015; 93:119.

36. Agarwal A, Saleh RA, Bedaiwy MA. Role of reactive oxygen species in the pathophysiology of human reproduction. Fertil Steril 2003;79:829-43.

37. Du Plessis SS, Agarwal A, Halabi J, Tvrda E. Contemporary evidence on the physiological role of reactive oxygen species in human sperm function. J Assist Reprod Genet 2015;32: 509-20.

38. O’Flaherty C. Redox regulation of mammalian sperm capacitation. Asian J Androl 2015;17:583-90.

39. Walczak-Jedrzejowska R, Wolski JK, Slowikowska-Hilczer J. The role of oxidative stress and antioxidants in male fertility. Cent European J Urol 2013;66:60-7.

40. Agarwal A, Cho CL, Esteves SC, Majzoub A. Reactive oxygen species and sperm DNA fragmentation. Transl Androl Urol 2017;6:S695-6.

41. Agarwal A, Ikemoto I, Loughlin KR. Relationship of sperm parameters with levels of reactive oxygen species in semen specimens. J Urol 1994;152:107-10.

42. Menezo Y, Evenson DP, Cohen M, Dale B. Effect of antioxidants on sperm genetic damage. In: Baldi E, Muratori M, editors. Genetic damage in human spermatozoa. New York: Springer; 2014;173-89.

43. Truong T, Gardner DK. Antioxidants improve IVF outcome and subsequent embryo development in the mouse. Hum Reprod 2017;32:2404-13.

44. Bisht S, Faiq M, Tolahunase M, Dada R. Oxidative stress and male infertility. Nat Rev Urol 2017;14:470-85.
45. Muratori M, Tamburrino L, Marchiani S, Cambi M, Olivito $\mathrm{B}$, Azzari C, et al. Investigation on the origin of sperm DNA fragmentation: role of apoptosis, immaturity and oxidative stress. Mol Med 2015;21:109-22.

46. Aitken RJ. DNA damage in human spermatozoa; important contributor to mutagenesis in the offspring. Transl Androl Urol 2017;6:S761-4.

47. Agarwal A, Allamaneni SS. Free radicals and male reproduction. J Indian Med Assoc 2011;109:184-7.

48. Tremellen K. Treatment of sperm oxidative stress: a collaborative approach between clinician and embryologist. In: Henkel R, Samanta L, Agarwal A, editors. Oxidants, antioxidants, and impact of the oxidative status in male reproduction. London: Elsevier/Academic Press; 2018;225-35.

49. Agarwal A, Rana M, Qiu E, AlBunni H, Bui AD, Henkel R. Role of oxidative stress, infection and inflammation in male infertility. Andrologia 2018;50:e13126.

50. Shekarriz M, Thomas AJ Jr, Agarwal A. Incidence and level of seminal reactive oxygen species in normal men. Urology 1995;45:103-7.

51. Ochsendorf FR, Thiele J, Fuchs J, Schüttau H, Freisleben HJ, Buslau M, et al. Chemiluminescence in semen of infertile men. Andrologia 1994;26:289-93.

52. Henkel R, Sandhu IS, Agarwal A. The excessive use of antioxidant therapy: a possible cause of male infertility? Andrologia 2019;51:e13162.

53. Ross C, Morriss A, Khairy M, Khalaf Y, Braude P, Coomarasamy A, et al. A systematic review of the effect of oral antioxidants on male infertility. Reprod Biomed Online 2010;20: 711-23.

54. Adewoyin M, Ibrahim M, Roszaman R, Isa MLM, Alewi NAM, Rafa AAA, et al. Male infertility: the effect of natural antioxidants and phytocompounds on seminal oxidative stress. Diseases 2017;5:E9.

55. Dada R, Shamsi MB, Venkatesh S, Gupta NP, Kumar R. Attenuation of oxidative stress \& DNA damage in varicocelectomy: implications in infertility management. Indian J Med Res 2010;132:728-30.

56. Chen SS, Huang WJ, Chang LS, Wei YH. Attenuation of oxidative stress after varicocelectomy in subfertile patients with varicocele. J Urol 2008;179:639-42.

57. Agarwal A, Gupta S, Sharma R. Reactive oxygen species (ROS) measurement. In: Agarwal A, Gupta S, Sharma R, editors. Andrological evaluation of male infertility: a laboratory guide. Cham: Springer International Publishing; 2016;15563.

58. Agarwal A, Roychoudhury S, Sharma R, Gupta S, Majzoub A, Sabanegh E. Diagnostic application of oxidation-reduction 
potential assay for measurement of oxidative stress: clinical utility in male factor infertility. Reprod Biomed Online 2017; 34:48-57.

59. Agarwal A, Panner Selvam MK, Arafa M, Okada H, Homa $\mathrm{S}$, Killeen A, et al. Multi-center evaluation of oxidationreduction potential by the MiOXSYS System in males with abnormal semen. Asian J Androl 2019. doi: 10.4103/aja. aja_5.19 [Epub].

60. Ko EY, Sabanegh ES Jr, Agarwal A. Male infertility testing: reactive oxygen species and antioxidant capacity. Fertil Steril 2014;102:1518-27.

61. Thonneau P, Marchand S, Tallec A, Ferial ML, Ducot B, Lansac J, et al. Incidence and main causes of infertility in a resident population $(1,850,000)$ of three French regions (1988-1989). Hum Reprod 1991;6:811-6.

62. Agarwal A, Virk G, Ong C, du Plessis SS. Effect of oxidative stress on male reproduction. World J Mens Health 2014;32:117.

63. Jarow J, Sigman M, Kolettis PN, Lipshultz LR, McClure RD, Nangia AK, et al. The optimal evaluation of the infertile male: AUA best practice statement reviewed and validity confirmed 2011. Linthicum: American Urological Association; 2011.

64. Esteves SC, Sharma RK, Gosálvez J, Agarwal A. A translational medicine appraisal of specialized andrology testing in unexplained male infertility. Int Urol Nephrol 2014;46:103752.

65. Patel AS, Leong JY, Ramasamy R. Prediction of male infertility by the World Health Organization laboratory manual for assessment of semen analysis: a systematic review. Arab J Urol 2017;16:96-102.

66. Wang C, Swerdloff RS. Limitations of semen analysis as a test of male fertility and anticipated needs from newer tests. Fertil Steril 2014;102:1502-7.

67. Esteves SC, Zini A, Aziz N, Alvarez JG, Sabanegh ES Jr, Agarwal A. Critical appraisal of World Health Organization's new reference values for human semen characteristics and effect on diagnosis and treatment of subfertile men. Urology 2012;79:16-22.

68. Bonde JP, Ernst E, Jensen TK, Hjollund NH, Kolstad H, Henriksen TB, et al. Relation between semen quality and fertility: a population-based study of 430 first-pregnancy planners. Lancet 1998;352:1172-7.

69. Agarwal A, Sharma R, Roychoudhury S, Du Plessis S, Sabanegh E. MiOXSYS: a novel method of measuring oxidation reduction potential in semen and seminal plasma. Fertil Steril 2016;106:566-73.e10.

70. Samanta L, Agarwal A, Swain N, Sharma R, Gopalan B, Es- teves SC, et al. Proteomic signatures of sperm mitochondria in varicocele: clinical use as biomarkers of varicocele associated infertility. J Urol 2018;200:414-22.

71. Arafa M, Agarwal A, Al Said S, Majzoub A, Sharma R, Bjugstad KB, et al. Semen quality and infertility status can be identified through measures of oxidation-reduction potential. Andrologia 2018;50:e12881.

72. Homa ST, Vassiliou AM, Stone J, Killeen AP, Dawkins A, Xie J, et al. A comparison between two assays for measuring seminal oxidative stress and their relationship with sperm DNA fragmentation and semen parameters. Genes (Basel) 2019;10:E236.

73. Okouchi S, Suzuki M, Sugano K, Kagamimori S, Ikeda S. Water desirable for the human body in terms of oxidationreduction potential (ORP) to $\mathrm{pH}$ relationship. J Food Sci 2002;67:1594-8.

74. Grotto D, Santa Maria LD, Boeira S, Valentini J, Charão MF, Moro AM, et al. Rapid quantification of malondialdehyde in plasma by high performance liquid chromatography-visible detection. J Pharm Biomed Anal 2007;43:619-24.

75. Vessey W, Perez-Miranda A, Macfarquhar R, Agarwal A, Homa S. Reactive oxygen species in human semen: validation and qualification of a chemiluminescence assay. Fertil Steril 2014;102:1576-83.e4.

76. Agarwal A, Roychoudhury S, Bjugstad KB, Cho CL. Oxidation-reduction potential of semen: what is its role in the treatment of male infertility? Ther Adv Urol 2016;8:302-18.

77. Agarwal A, Qiu E, Sharma R. Laboratory assessment of oxidative stress in semen. Arab J Urol 2017;16:77-86.

78. Agarwal A, Wang SM. Clinical relevance of oxidation-reduction potential in the evaluation of male infertility. Urology 2017;104:84-9.

79. Agarwal A, Arafa MM, Elbardisi H, Majzoub A, Alsaid SS. Relationship between seminal oxidation reduction potential and sperm DNA fragmentation in infertile men. Fertil Steril 2017;108:e316.

80. Agarwal A, Gupta S, Sharma R. Oxidation-reduction potential measurement in ejaculated semen samples. In: Agarwal A, Gupta S, Sharma R, editors. Andrological evaluation of male infertility: a laboratory guide. Cham: Springer International Publishing; 2016;165-70.

81. Majzoub A, Arafa M, Mahdi M, Agarwal A, Al Said S, AlEmadi I, et al. Oxidation-reduction potential and sperm DNA fragmentation, and their associations with sperm morphological anomalies amongst fertile and infertile men. Arab J Urol 2018;16:87-95.

82. Ko EY, Siddiqi K, Brannigan RE, Sabanegh ES Jr. Empirical medical therapy for idiopathic male infertility: a survey of 
the American Urological Association. J Urol 2012;187:973-8.

83. Kim HH, Schlegel PN. Endocrine manipulation in male infertility. Urol Clin North Am 2008;35:303-18.

84. Jung JH, Seo JT. Empirical medical therapy in idiopathic male infertility: promise or panacea? Clin Exp Reprod Med 2014;41:108-14.

85. Tadros NN, Sabanegh ES. Empiric medical therapy with hormonal agents for idiopathic male infertility. Indian J Urol 2017;33:194-8.

86. Nieschlag E, Kamischke A. Empirical therapies for idiopathic male infertility. In: Nieschlag E, Behre HM, Nieschlag S, editors. Andrology: male reproductive health and dysfunction. Berlin, Heidelberg: Springer Berlin Heidelberg; 2010;457-67.

87. Attia AM, Abou-Setta AM, Al-Inany HG. Gonadotrophins for idiopathic male factor subfertility. Cochrane Database Syst Rev 2013:CD005071.

88. Kumar R, Gautam G, Gupta NP. Drug therapy for idiopathic male infertility: rationale versus evidence. J Urol 2006;176: 1307-12.

89. Clark RV, Sherins RJ. Treatment of men with idiopathic oligozoospermic infertility using the aromatase inhibitor, testolactone. Results of a double-blinded, randomized, placebocontrolled trial with crossover. J Androl 1989;10:240-7.

90. Siddiq FM, Sigman M. A new look at the medical management of infertility. Urol Clin North Am 2002;29:949-63.

91. Mirończuk-Chodakowska I, Witkowska AM, Zujko ME. Endogenous non-enzymatic antioxidants in the human body. Adv Med Sci 2018;63:68-78.

92. Halliwell B, Gutteridge JMC. Antioxidant defences synthesized in vivo. In: Halliwell B, Gutteridge JMC, editors. Free radicals in biology and medicine. 5th ed. Oxford: Oxford University Press; 2015.

93. Majzoub A, Agarwal A. Antioxidant therapy in idiopathic oligoasthenoteratozoospermia. Indian J Urol 2017;33:20714.

94. Hsieh YY, Sun YL, Chang CC, Lee YS, Tsai HD, Lin CS. Superoxide dismutase activities of spermatozoa and seminal plasma are not correlated with male infertility. J Clin Lab Anal 2002;16:127-31.

95. Kobayashi T, Miyazaki T, Natori M, Nozawa S. Protective role of superoxide dismutase in human sperm motility: superoxide dismutase activity and lipid peroxide in human seminal plasma and spermatozoa. Hum Reprod 1991;6:98791.

96. Ben Abdallah F, Dammak I, Attia H, Hentati B, Ammar-Keskes L. Lipid peroxidation and antioxidant enzyme activities in infertile men: correlation with semen parameter. J Clin Lab Anal 2009;23:99-104.
97. Lenzi A, Lombardo F, Gandini L, Culasso F, Dondero F. Glutathione therapy for male infertility. Arch Androl 1992;29: 65-8.

98. Lenzi A, Culasso F, Gandini L, Lombardo F, Dondero F. Placebo-controlled, double-blind, cross-over trial of glutathione therapy in male infertility. Hum Reprod 1993;8:1657-62.

99. Atig F, Raffa M, Habib BA, Kerkeni A, Saad A, Ajina M. Impact of seminal trace element and glutathione levels on semen quality of Tunisian infertile men. BMC Urol 2012;12:6.

100. Dawson EB, Harris WA, Rankin WE, Charpentier LA, McGanity WJ. Effect of ascorbic acid on male fertility. Ann N Y Acad Sci 1987;498:312-23.

101. Akmal M, Qadri JQ, Al-Waili NS, Thangal S, Haq A, Saloom KY. Improvement in human semen quality after oral supplementation of vitamin C. J Med Food 2006;9:440-2.

102. Suleiman AA, Alboqai OK, Yasein N, Al-Essa MK, El Masri $K$. Prevalence of vitamin-mineral supplement use among Jordan University students. Saudi Med J 2008;29:1326-31.

103. Kessopoulou E, Powers HJ, Sharma KK, Pearson MJ, Russell JM, Cooke ID, et al. A double-blind randomized placebo cross-over controlled trial using the antioxidant vitamin $\mathrm{E}$ to treat reactive oxygen species associated male infertility. Fertil Steril 1995;64:825-31.

104. Nadjarzadeh A, Shidfar F, Amirjannati N, Vafa MR, Motevalian SA, Gohari MR, et al. Effect of coenzyme Q10 supplementation on antioxidant enzymes activity and oxidative stress of seminal plasma: a double-blind randomised clinical trial. Andrologia 2014;46:177-83.

105. Tvrda E, Peer R, Sikka SC, Agarwal A. Iron and copper in male reproduction: a double-edged sword. J Assist Reprod Genet 2015;32:3-16.

106. Zhao J, Dong X, Hu X, Long Z, Wang L, Liu Q, et al. Zinc levels in seminal plasma and their correlation with male infertility: a systematic review and meta-analysis. Sci Rep 2016;6:22386.

107. Ahsan U, Kamran Z, Raza I, Ahmad S, Babar W, Riaz MH, et al. Role of selenium in male reproduction: a review. Anim Reprod Sci 2014;146:55-62.

108. Ciftci H, Verit A, Savas M, Yeni E, Erel O. Effects of N-acetylcysteine on semen parameters and oxidative/antioxidant status. Urology 2009;74:73-6.

109. Oeda T, Henkel R, Ohmori H, Schill WB. Scavenging effect of $\mathrm{N}$-acetyl-L-cysteine against reactive oxygen species in human semen: a possible therapeutic modality for male factor infertility? Andrologia 1997;29:125-31.

110. Stanislavov R, Rohdewald P. Sperm quality in men is improved by supplementation with a combination of Larginine, L-citrullin, roburins andPycnogenol ${ }^{\circledR}$. Minerva 
Urol Nefrol 2014;66:217-23.

111. Wong WY, Merkus HM, Thomas CM, Menkveld R, Zielhuis GA, Steegers-Theunissen RP. Effects of folic acid and zinc sulfate on male factor subfertility: a double-blind, randomized, placebo-controlled trial. Fertil Steril 2002;77:491-8.

112. Castagné V, Lefèvre K, Natero R, Clarke PG, Bedker DA. An optimal redox status for the survival of axotomized ganglion cells in the developing retina. Neuroscience 1999;93:313-20.

113. Busetto GM, Agarwal A, Virmani A, Antonini G, Ragonesi G, Del Giudice F, et al. Effect of metabolic and antioxidant supplementation on sperm parameters in oligo-asthenoteratozoospermia, with and without varicocele: a doubleblind placebo-controlled study. Andrologia 2018;50:e12927.

114. Safarinejad MR. Efficacy of coenzyme Q10 on semen parameters, sperm function and reproductive hormones in infertile men. J Urol 2009;182:237-48.

115. Balercia G, Regoli F, Armeni T, Koverech A, Mantero F, Boscaro M. Placebo-controlled double-blind randomized trial on the use of L-carnitine, L-acetylcarnitine, or combined $\mathrm{L}$-carnitine and L-acetylcarnitine in men with idiopathic asthenozoospermia. Fertil Steril 2005;84:662-71.

116. Safarinejad MR, Safarinejad S, Shafiei N, Safarinejad S. Effects of the reduced form of coenzyme Q10 (ubiquinol) on semen parameters in men with idiopathic infertility: a double-blind, placebo controlled, randomized study. J Urol 2012;188:526-31.

117. ElSheikh MG, Hosny MB, Elshenoufy A, Elghamrawi H, Fayad A, Abdelrahman S. Combination of vitamin E and clomiphene citrate in treating patients with idiopathic oligoasthenozoospermia: a prospective, randomized trial. Andrology 2015;3:864-7.

118. Majzoub A, Agarwal A, Esteves SC. Antioxidants for elevated sperm DNA fragmentation: a mini review. Transl Androl Urol 2017;6:S649-53.

119. Micic S, Lalic N, Djordjevic D, Bojanic N, BogavacStanojevic N, Busetto GM, et al. Double-blind, randomised, placebo-controlled trial on the effect of L-carnitine and Lacetylcarnitine on sperm parameters in men with idiopathic oligoasthenozoospermia. Andrologia 2019;51:e13267.

120. Balercia G, Buldreghini E, Vignini A, Tiano L, Paggi F, Amoroso S, et al. Coenzyme Q10 treatment in infertile men with idiopathic asthenozoospermia: a placebo-controlled, doubleblind randomized trial. Fertil Steril 2009;91:1785-92.

121. Tunc O, Thompson J, Tremellen K. Improvement in sperm DNA quality using an oral antioxidant therapy. Reprod Biomed Online 2009;18:761-8.

122. Tremellen K, Miari G, Froiland D, Thompson J. A randomised control trial examining the effect of an antioxidant
(Menevit) on pregnancy outcome during IVF-ICSI treatment. Aust N Z J Obstet Gynaecol 2007;47:216-21.

123. Imamovic Kumalic S, Pinter B. Review of clinical trials on effects of oral antioxidants on basic semen and other parameters in idiopathic oligoasthenoteratozoospermia. Biomed Res Int 2014;2014:426951.

124. Lampiao F. Free radicals generation in an in vitro fertilization setting and how to minimize them. World J Obstet Gynecol 2012;1:29-34.

125. Bedaiwy MA, Falcone T, Mohamed MS, Aleem AA, Sharma RK, Worley SE, et al. Differential growth of human embryos in vitro: role of reactive oxygen species. Fertil Steril 2004;82: 593-600.

126. Showell MG, Mackenzie-Proctor R, Brown J, Yazdani A, Stankiewicz MT, Hart RJ. Antioxidants for male subfertility. Cochrane Database Syst Rev 2014;(12):CD007411.

127. Mora-Esteves C, Shin D. Nutrient supplementation: improving male fertility fourfold. Semin Reprod Med 2013;31:293300 .

128. Gil-Villa AM, Cardona-Maya W, Agarwal A, Sharma R, Cadavid A. Role of male factor in early recurrent embryo loss: do antioxidants have any effect? Fertil Steril 2009;92:565-71.

129. Calogero AE, Duca Y, Condorelli RA, La Vignera S. Male accessory gland inflammation, infertility, and sexual dysfunctions: a practical approach to diagnosis and therapy. Andrology 2017;5:1064-72.

130. La Vignera S, Vicari E, Condorelli RA, D’Agata R, Calogero AE. Male accessory gland infection and sperm parameters (review). Int J Androl 2011;34:e330-47.

131. Colpi GM, Francavilla S, Haidl G, Link K, Behre HM, Goulis DG, et al. European Academy of Andrology guideline Management of oligo-astheno-teratozoospermia. Andrology 2018;6:513-24

132. Haidl G, Haidl F, Allam JP, Schuppe HC. Therapeutic options in male genital tract inflammation. Andrologia 2019; 51:e13207.

133. Barratt CLR, Björndahl L, De Jonge CJ, Lamb DJ, Osorio Martini F, McLachlan R, et al. The diagnosis of male infertility: an analysis of the evidence to support the development of global WHO guidance-challenges and future research opportunities. Hum Reprod Update 2017;23:660-80.

134. Atik RB, Christiansen OB, Elson J, Kolte AM, Lewis S, Middeldorp S, et al. ESHRE guideline: recurrent pregnancy loss. Hum Reprod Open 2018. doi: 10.1093/hropen/hoy002.

135. Henkel RR. Leukocytes and oxidative stress: dilemma for sperm function and male fertility. Asian J Androl 2011;13: 43-52.

136. Gutteridge JM, Halliwell B. Antioxidants: molecules, medi- 


\section{MEN's HEALTH}

cines, and myths. Biochem Biophys Res Commun 2010;393: 561-4.

137. Pérez-Torres I, Guarner-Lans V, Rubio-Ruiz ME. Reductive stress in inflammation-associated diseases and the prooxidant effect of antioxidant agents. Int J Mol Sci 2017;18: E2098.

138. Ufer C, Wang CC, Borchert A, Heydeck D, Kuhn H. Redox control in mammalian embryo development. Antioxid Re-
Ashok Agarwal, et al: Male Oxidative Stress Infertility

dox Signal 2010;13:833-75.

139. Hendin BN, Kolettis PN, Sharma RK, Thomas AJ Jr, Agarwal A. Varicocele is associated with elevated spermatozoal reactive oxygen species production and diminished seminal plasma antioxidant capacity. J Urol 1999;161:1831-4.

140. Harlev A, Agarwal A, Gunes SO, Shetty A, du Plessis SS. Smoking and male infertility: an evidence-based review. World J Mens Health 2015;33:143-60. 
Appendix. Key terminologies

MOSI

ROS

MiOXSYS

ORP

Oxidative stress

Reductive stress
Infertile men with abnormal semen characteristics and oxidative stress, which includes many patients who were previously classified as having idiopathic male infertility.

Reactive oxygen species (ROS) are compounds of oxygen radicals such as superoxide anion $\left(\mathrm{O}_{2}^{-}\right)$, hydrogen peroxide $\left(\mathrm{H}_{2} \mathrm{O}_{2}\right)$, hypochlorite $(\mathrm{OHCl})$, and hydroxyl radical $(\mathrm{OH})$ containing free, unpaired electrons in their outer orbit, which makes them highly unstable and reactive [57].

MiOXSYS is a novel technology used to measure oxidation-reduction potential (ORP) in semen based on a galvanostatic measure of electrons [58].

ORP is a measure of the relationship between oxidants and antioxidants that provides a comprehensive measure of the redox system. ORP cut-off value $1.34 \mathrm{mV} / 10^{6}$ sperm $/ \mathrm{mLv}$ identified normal semen and abnormal semen quality with a sensitivity $98.1 \%$, specificity $40.6 \%$, positive predictive value $94.7 \%$ and negative predictive value $66.6 \%$ [59].

Indication of seminal ORP includes men with abnormal semen analysis and male infertility.

Oxidative stress occurs (OS) when there is an imbalance between ROS and the antioxidants that scavenge surplus free radicals [24].

A shift of the bodily redox levels into a more reduced state is called reductive stress. Overdosing on antioxidants causes reductive stress [52]. 